\title{
Studies of the effect of growth promoting hormones on rooting of cutting in Caralluma (Caralluma sarkariae) Lavranos \& Frandsen
}

\author{
GG Kannan, K Rajamani, L Nalina \& D Uma
}

Journal of Agriculture and Ecology

Volume-8 (December, 2019)

ISSN: 2456-9410

\section{Journal of Agriculture} and Ecology

ISSN: 2456-9410

Volume: 8

Journal of Agriculture and Ecology (2019) 8: 46-51 http://doi.org/10.53911/JAE.2019.8206 


\title{
Studies of the effect of growth promoting hormones on rooting of cutting in Caralluma (Caralluma sarkariae) Lavranos \& Frandsen
}

\author{
GG Kannan ${ }^{1} \bar{L}, \mathrm{~K}$ Rajamani ${ }^{2}$, L Nalina ${ }^{3} \& \mathrm{D} \mathrm{Uma}^{4}$ \\ ${ }^{1,2,3}$ Dept. of Medicinal and Aromatic Crops, HC \& RI, \\ ${ }^{4}$ Dept. of Biochemistry, Tamil Nadu Agricultural University, Coimbatore-3. \\ $\triangle$ Corresponding author: G Gokula Kannan, Email: bpgkannan@gmail.com \\ Article Info \\ Article history \\ Received: 25 September 2018 \\ Accepted: 20 November 2018 \\ Available online: 5 August 2019 \\ Key Words: \\ Caralluma sarkariae, \\ IAA, IBA, anti-obesity, \\ kallimudaiyan.

\section{Abstract} \\ Caralluma sarkariae is a succulent herb belongs to the family of \\ Apocyanaceae. The population of Caralluma sarkariaeis found growing in a \\ secluded area at Nagamalai hills of Madurai, Tamil Nadu. The crop with its \\ immense medicinal value such as anti-obesity and anti-diabetic properties \\ need to be explored and promoted in non-traditional areas. Hence the \\ experiment was taken up to study the effect of growth regulators on rooting \\ of cuttings in Caralluma sarkariae. The results revealed that, the use of \\ growth regulators greatly influenced on growth parameters particularly shoot \\ and root length, when side shoots were treated with IBA $200 \mathrm{ppm}$.
}

Copyright (02019 Kannan et al., This is an open access article published under the terms of the Creative Commons Attribution License, which permits unrestricted use, distribution, and reproduction in any medium, provided the original work is properly cited.

Preferred citation: Kannan GG, Rajamani K, Nalina L \& Uma D. 2019. Studies of the effect of growth promoting hormones on rooting of cutting in Caralluma (Caralluma sarkariae) Lavranos \& Frandsen. Journal of Agriculture and Ecology, 8: 46-51; http://doi.org/10.53911/JAE.2019.8206.

\section{Introduction}

Caralluma sarkariae $(2 \mathrm{n}=22$, Family: Apocynaceae), the endemic succulent herb is an important indigenous medicinal plant with restricted distribution in India. Caralluma species have been documented in the Arabic and Indian traditional medicines. This plant contains glycosides which are reported to be the main reason for the medicinal activity (Ramesh et al. 1999). Pharmacological activities of Caralluma species have been reported for appetite suppression, anti-obesity activities, anti-inflammatory activity, analgesic activity, anxiolytic activity, antiatherogenic activity, wounds healing and antibacterial activity (Devi \& Dhamotharan 2016).Caralluma sarkariae has been reported to be distributed in few habitats of Madurai district in Tamil Nadu and the range of variation in distribution, floral features such as hairiness, striation patterns in the species was reported (Aditya 2009). In India, Caralluma is cooked as a vegetable and is used in preserves such as chutneys and pickles. It is also eaten raw. In Western India, Caralluma fimbriata is a famine food suppressing appetite and for quenching thirst. The hunting tribe's chew chunks of the Caralluma cactus to suppress hunger and thirst when on a long hunt. 
Caralluma is difficult to germinate through seeds and successful attempts were made to improve the seed germination as well as vegetative methods (Samydurai \& Thangapandian 2012). The Growth regulators can help in induction of early and enhanced rooting. Auxin is one of the important plant growth regulator and the main role of auxin is stimulation and initiation of roots from cuttings (Cline 2000).

\section{Materials and Methods}

The experimental nursery was located at Botanical Garden, Department of Medicinal and Aromatic Crops, Horticultural College and Research Institute, TNAU, Coimbatore during 2017-2018.Caralluma sarkariae planting materials were collected from Horticultural College and Research Institute, Periyakulam, Theni district. The plant collection site is located at an altitude of 300 $\mathrm{m}$ above mean sea level with geographical bearing of $10^{\circ} 12^{\prime} \mathrm{N}$ latitude and $77^{\circ} 35^{\prime} \mathrm{E}$ longitude. The collected plants given to Botanical Survey of India for species authentication. The experiment was consisted of two factors viz., type of cutting and growth regulators and main stem $\left(\mathrm{F}_{1}\right)$ and side shoots $\left(\mathrm{F}_{2}\right)$ were taken for planting. The prepared stem cuttings were dipped in freshly prepared plant growth regulator of concerned treatments solution. After the treatment, every group of treated stem cuttings were planted in 10 poly bags per treatments. The experiment was laid out in FCRD with three replications. The treatments details were given below.

\begin{tabular}{|c|c|}
\hline Factors (F) & $\begin{array}{l}\text { Treatment with } \\
\text { concentrations }\end{array}$ \\
\hline \multirow{5}{*}{ Main stem $\left(\mathrm{F}_{1}\right)$} & $\mathrm{T}_{1}$-IBA $200 \mathrm{ppm}$ \\
\hline & $\mathrm{T}_{2}$-IBA $400 \mathrm{ppm}$ \\
\hline & $\mathrm{T}_{3}$-IBA $600 \mathrm{ppm}$ \\
\hline & $\mathrm{T}_{4}$-IBA $800 \mathrm{ppm}$ \\
\hline & $\mathrm{T}_{5}$-IBA1000 ppm \\
\hline \multirow[t]{6}{*}{ Side-shoots $\left(\mathrm{F}_{2}\right)$} & $\mathrm{T}_{6}$-IAA $200 \mathrm{ppm}$ \\
\hline & $\mathrm{T}_{7}$-IAA $400 \mathrm{ppm}$ \\
\hline & $\mathrm{T}_{8}$-IAA $600 \mathrm{ppm}$ \\
\hline & $\mathrm{T}_{9}$-IAA $800 \mathrm{ppm}$ \\
\hline & $\mathrm{T}_{10}$-IAA1000 ppm \\
\hline & Control \\
\hline
\end{tabular}

Results and Discussion

Significant variation was observed among plant growth regulators, stem cuttings and their interactions. Among the two propagules viz., main shoot and side shoot, the side shoot recorded the highest mean shoot length of $13.32 \mathrm{~cm}$ as compared to the main shoot of $10.89 \mathrm{~cm}$. Between the growth regulators, the shoot length was highest of $15.82 \mathrm{~cm}$ in IBA $200 \mathrm{ppm}\left(\mathrm{T}_{1}\right)$ followed by IBA $400 \mathrm{ppm}\left(\mathrm{T}_{2}\right)$ and the lowest of $9.82 \mathrm{~cm}$ in IBA $1000 \mathrm{ppm}\left(\mathrm{T}_{5}\right)$. The interaction effect was significant indicating that, the highest shoot length of $17.34 \mathrm{~cm}$ was recorded in main stem treated with IBA 200 ppm followed by IAA $600 \mathrm{ppm}$ with $13.04 \mathrm{~cm}$ and the lowest of $8.54 \mathrm{~cm}$ in IBA $600 \mathrm{ppm}$. The root length was highest $(7.31 \mathrm{~cm})$ in side shoots while it was $5.91 \mathrm{~cm}$ in main stem. The mean root length of growth regulators indicated that, the highest mean root length of $9.64 \mathrm{~cm}$ was observed in IAA $1000 \mathrm{ppm}\left(\mathrm{T}_{10}\right)$ followed by IAA $600 \mathrm{ppm}\left(\mathrm{T}_{8}\right)$. While low mean root length was observed in IBA $1000 \mathrm{ppm}\left(\mathrm{T}_{5}\right)$ which recorded $3.98 \mathrm{~cm}$. The interaction effect was also significant which indicated that, the highest root length of $10.46 \mathrm{~cm}$ was 
recorded in main stem when used as a propagule treated with IAA $1000 \mathrm{ppm}$. The lowest length of $2.83 \mathrm{~cm}$ was recorded in main stem treated with IBA 1000 ppm.The side shoots recorded more number of shoots of $2.29 \mathrm{~cm}$ when compared to the main shoots of $2.10 \mathrm{~cm}$. Among the various growth regulators treatments, IBA 200 ppm $\left(\mathrm{T}_{1}\right)$ recorded highest number of shoots (3.10) followed by IBA $1000\left(\mathrm{~T}_{5}\right)$ and $600 \mathrm{ppm}\left(\mathrm{T}_{3}\right)$ with $2.50 \mathrm{~cm}$ and lowest in IAA $400 \mathrm{ppm}\left(\mathrm{T}_{7}\right)$ of $1.70 \mathrm{~cm}$. The interaction effect was significant indicating that, the highest number of shoots with $3.60 \mathrm{~cm}$ was recorded in the main shoots treated with IBA $200 \mathrm{ppm}$ and lowest in IAA $1000 \mathrm{ppm}$ with $0.40 \mathrm{~cm}$ and the side shoots treated with IAA $1000 \mathrm{ppm} 0.80 \mathrm{~cm}$ (Table 1). High mean number of roots was observed in side shoots of $22.34 \mathrm{~cm}$ followed by main shoots of $14.65 \mathrm{~cm}$. Between the growth regulators, IBA $200 \mathrm{ppm}\left(\mathrm{T}_{1}\right)$ recorded the highest number of roots $26.90 \mathrm{~cm}$ followed by IAA $600 \mathrm{ppm}\left(\mathrm{T}_{8}\right)$ with $23.70 \mathrm{~cm}$, IAA 800 ppm $\left(\mathrm{T}_{9}\right) 23.00$ and IBA $400 \mathrm{ppm}\left(\mathrm{T}_{2}\right) 21.00$. Among interactions effects, the side shoots treated with IBA $800 \mathrm{ppm}$ recorded the highest number of roots of $31.40 \mathrm{~cm}$ followed by the main stems treated with IBA $200 \mathrm{ppm}$ of $27.40 \mathrm{~cm}$, side shoots with IBA $400 \mathrm{ppm}$ of $27.00 \mathrm{~cm}$ and IBA $200 \mathrm{ppm}$ of $26.40 \mathrm{~cm}$. Whereas the lowest values on interaction was observed in main stem treated with IAA 200 ppm of $9.00 \mathrm{~cm}$ followed by IAA $400 \mathrm{ppm}$ of $9.20 \mathrm{~cm}$. Higher establishment percentage was observed in the side shoots with $82.72 \%$ followed by $42.42 \%$. Between the growth regulators, IBA $200 \mathrm{ppm}\left(\mathrm{T}_{1}\right)$ recorded the highest percentage of $76.66 \%$ followed by IBA $400 \mathrm{ppm}\left(\mathrm{T}_{2}\right)$ and lowest establishment per cent in IAA $800 \mathrm{ppm}$ of $53.33 \%$. The interaction effect was significant indicating that, the side shoots treated with IBA 200 ppm, 400 ppm and also the control recorded the highest establishment percentage $100 \%$ followed by $86.66 \%$ in IBA $600 \mathrm{ppm}$. The lowest percentage of establishment (36.66\%) was observed the main shoots treated with IAA $400 \mathrm{ppm}$ and $600 \mathrm{ppm}$. High mean on rooting percentage was observed in main shoots $42.42 \%$ followed by side shoots with $79.99 \%$. Between the growth regulators, IBA 200 ppm recorded the highest rooting percentage of $71.66 \%$ while IAA $800 \mathrm{ppm}$ $\left(\mathrm{T}_{9}\right)$ recorded the lowest with $53.33 \%$. Among the interaction, the highest rooting percentage 90.00 was recorded in side shoots treated with IBA $200 \mathrm{ppm}$. The lowest rooting percentage was recorded in side shoots treated with IAA 400 ppm and 600 ppm with $36.66 \%$ respectively (Table 2).

In the present experiment, the side shoots performed better than the main stem. Caralluma is a succulent plant and rooting is often correlated with the maturity of tissues. The main stem is often hardy as compared to the side shoots which are young and responds to rooting. Moreover, the side shoots emerges out of the main stem and has a basal node which strikes root easily when in contact with the media. This is probably the reason why the side shoots performed better in establishment and plant growth. Aruna et al. (2009) reported that xerophytic plants such as Caralluma are best propagated by separation of side shoots which respond to rooting when compared to the hardy shoots. Among the growth regulators, IBA at $200 \mathrm{ppm}$ recorded 
higher shoot length than the control. IBA is the most effective hormone and also persistent which helps in early sprouting. It do not translocate from the place of application which helps in cell elongation and growth stimulation thereby results in longer shoots. Similar report on the action of IBA on shoot characters was reported by (Ingle \& Venugopal 2009) in Stevia rebaudiana and (Murthy et al. 2010) in vanilla. Among the type of cuttings, main stem as a propagule recorded high number of shoots, shoot length, compared to the side shoot. It may be due to the presence of auxin in the main stem which enhanced the cell division and cell enlargement and resulted in improved vegetative growth (Evans 1973). Moreover the combined effects on treatment of main stem with IBA at lower concentration were observed with positive results. Similar trend was followed in the findings of (Francis et al. 1993) in black pepper, allspice by (Rema et al. 2008), bael by (Yashwanti et al. 2017) and guggal by (Jitendra et al. 2009). In Caralluma sarkariae, higher root length was recorded in the side shoots when compared to the main stem. Among the growth regulators, IAA 1000 ppm resulted in higher root length. The better length of roots is probably due to the presence of auxin for early differentiation and enhancement of cell division. Acidification is a process in which auxin synthesis the structural protein for increasing the formation of root length (Audus 1963). The findings of (Alagesaboopathi 2012) in Andrographis macrobotrys corroborated with results of the present study. The number of roots were also found to be higher in side shoots treated with IBA $200 \mathrm{ppm}$. The growth regulator IBA has high ability to promote root initiation (Rout \& Das 1994) and it produces strong and fibrous root system (Hitchcock \& Zimmerman 1940). Side shoots treated with IBA $200 \mathrm{ppm}$ and $400 \mathrm{ppm}$ registered the highest establishment percentage of shoots. Auxins like IBA and IAA when used at lower concentration results in better rooting and plant establishment. Use of lower concentrations of IBA and IAA are also helpful for elongation of roots paving way for better field establishment as explained by (Prakash 2005) in Nerium.

\section{Conclusion}

It is an evident from the present study that, Caralluma sarkariae can be propagated through stem cuttings. The growth regulators had remarkable influence on enhancing the growth parameters (shoots and roots), thereby increase in plant establishment rate. Among the different growth regulators IBA $200 \mathrm{ppm}$ was found to the best for multiplication of Caralluma sarkariae by stem cuttings in side shoots. 
Table 1. Effect of PGR on shoot length, root length and number of shoots

\begin{tabular}{|c|c|c|c|c|c|c|c|c|c|c|}
\hline \multirow[b]{2}{*}{ S.No } & \multirow[b]{2}{*}{ Treatments } & \multicolumn{2}{|c|}{ Shoot length $(\mathrm{cm})$} & \multirow[b]{2}{*}{ Mean } & \multicolumn{2}{|c|}{ Root length (cm) } & \multirow[b]{2}{*}{ Mean } & \multicolumn{2}{|c|}{$\begin{array}{l}\text { No .of. Shoots } \\
\text { (cm) }\end{array}$} & \multirow[b]{2}{*}{ Mean } \\
\hline & & $\begin{array}{l}\text { Main } \\
\text { stems }\end{array}$ & Sideshoots & & $\begin{array}{l}\text { Main } \\
\text { stems }\end{array}$ & Sideshoots & & $\begin{array}{l}\text { Main } \\
\text { stems }\end{array}$ & Sideshoots & \\
\hline 1 & $\mathrm{~T}_{1}$ & 17.34 & 14.30 & 15.82 & 7.34 & 6.46 & 6.90 & 3.60 & 2.60 & 3.10 \\
\hline 2 & $\mathrm{~T}_{2}$ & 12.66 & 14.48 & 13.57 & 5.30 & 5.42 & 5.36 & 2.40 & 2.60 & 2.50 \\
\hline 3 & $\mathrm{~T}_{3}$ & 8.54 & 12.20 & 10.37 & 4.38 & 7.60 & 5.99 & 1.80 & 3.20 & 2.50 \\
\hline 4 & $\mathrm{~T}_{4}$ & 9.08 & 13.46 & 11.27 & 3.08 & 6.82 & 4.95 & 2.40 & 2.20 & 2.30 \\
\hline 5 & $\mathrm{~T}_{5}$ & 10.20 & 9.44 & 9.82 & 2.83 & 5.14 & 3.98 & 2.00 & 3.20 & 2.60 \\
\hline 6 & $\mathrm{~T}_{6}$ & 9.14 & 14.46 & 11.80 & 4.80 & 6.04 & 5.42 & 2.40 & 2.00 & 2.20 \\
\hline 7 & $\mathrm{~T}_{7}$ & 8.68 & 14.66 & 11.67 & 5.12 & 9.12 & 7.12 & 1.40 & 2.00 & 1.70 \\
\hline 8 & $\mathrm{~T}_{8}$ & 13.04 & 15.46 & 14.25 & 7.86 & 9.90 & 8.88 & 2.40 & 2.40 & 2.40 \\
\hline 9 & $\mathrm{~T}_{9}$ & 12.30 & 10.94 & 11.62 & 8.15 & 7.66 & 7.90 & 2.40 & 1.20 & 1.80 \\
\hline 10 & $\mathrm{~T}_{1}$ & 8.78 & 12.42 & 10.60 & 10.46 & 8.82 & 9.64 & 0.40 & 0.80 & 0.60 \\
\hline 11 & Control & 10.10 & 14.78 & 12.44 & 5.75 & 7.50 & 6.62 & 2.00 & 3.00 & 2.50 \\
\hline \multirow{2}{*}{\multicolumn{2}{|c|}{ Mean }} & 10.89 & 13.32 & 12.11 & 5.91 & 7.31 & 6.61 & 2.10 & 2.29 & 2.20 \\
\hline & & $\mathrm{P}$ & PGR & $\mathrm{P} \times \mathrm{PGR}$ & $\mathrm{P}$ & PGR & $\mathrm{P} \times \mathrm{PGR}$ & $\mathrm{P}$ & PGR & $\mathrm{P} \times \mathrm{PGR}$ \\
\hline \multicolumn{2}{|c|}{$\mathrm{SE}(\mathrm{d})$} & 0.05 & 0.13 & 0.18 & 0.03 & 0.07 & 0.11 & 0.01 & 0.02 & 0.04 \\
\hline \multicolumn{2}{|c|}{$\mathrm{CD}(\mathrm{P}=0.05)$} & 0.11 & 0.27 & 0.38 & 0.06 & 0.16 & 0.22 & 0.02 & 0.05 & 0.08 \\
\hline
\end{tabular}

Table 2. Effect of PGR on number of roots, establishment and rooting percentage

\begin{tabular}{|c|c|c|c|c|c|c|c|c|c|c|}
\hline \multirow[t]{2}{*}{ S.No } & \multirow[t]{2}{*}{ Treatments } & \multicolumn{2}{|c|}{ No of roots $(\mathrm{cm})$} & \multirow[t]{2}{*}{ Mean } & \multicolumn{2}{|c|}{ Establishment\% } & \multirow[t]{2}{*}{ Mean } & \multicolumn{2}{|c|}{ Rooting \% } & \multirow[t]{2}{*}{ Mean } \\
\hline & & $\begin{array}{l}\text { Main } \\
\text { stems }\end{array}$ & Sideshoots & & $\begin{array}{l}\text { Main } \\
\text { stems }\end{array}$ & Sideshoots & & $\begin{array}{l}\text { Main } \\
\text { stems }\end{array}$ & Sideshoots & \\
\hline 1 & $\mathrm{~T}_{1}$ & 27.40 & 26.40 & 26.90 & 53.33 & 100.00 & 76.66 & 53.33 & 90.00 & 71.66 \\
\hline 2 & $\mathrm{~T}_{2}$ & 15.00 & 27.00 & 21.00 & 50.00 & 100.00 & 75.00 & 50.00 & 83.33 & 66.66 \\
\hline 3 & $\mathrm{~T}_{3}$ & 10.20 & 23.00 & 16.60 & 43.33 & 86.66 & 64.99 & 43.33 & 83.33 & 63.33 \\
\hline 4 & $\mathrm{~T}_{4}$ & 11.40 & 31.40 & 21.40 & 40.00 & 80.00 & 60.00 & 40.00 & 80.00 & 60.00 \\
\hline 5 & $\mathrm{~T}_{5}$ & 17.33 & 22.40 & 19.86 & 50.00 & 66.66 & 58.33 & 50.00 & 66.66 & 58.33 \\
\hline 6 & $\mathrm{~T}_{6}$ & 7.00 & 21.60 & 14.30 & 40.00 & 83.33 & 61.66 & 40.00 & 83.33 & 61.66 \\
\hline 7 & $\mathrm{~T}_{7}$ & 9.20 & 18.20 & 13.70 & 36.66 & 80.00 & 58.33 & 36.66 & 80.00 & 58.33 \\
\hline 8 & $\mathrm{~T}_{8^{-}}$ & 24.20 & 23.20 & 23.70 & 36.66 & 73.33 & 54.99 & 36.66 & 73.33 & 54.99 \\
\hline 9 & $\mathrm{~T}_{9}$ & 22.25 & 23.75 & 23.00 & 40.00 & 66.66 & 53.33 & 40.00 & 66.66 & 53.33 \\
\hline 10 & $\mathrm{~T}_{1}$ & 7.75 & 17.00 & 12.37 & 46.66 & 73.33 & 59.99 & 46.67 & 73.33 & 60.00 \\
\hline 11 & Control & 9.50 & 11.80 & 10.65 & 30.00 & 100.00 & 65.00 & 30.00 & 100.00 & 65.00 \\
\hline \multirow{2}{*}{\multicolumn{2}{|c|}{ Mean }} & 14.65 & 22.34 & 18.50 & 42.42 & 82.72 & 62.57 & 42.42 & 79.99 & 61.21 \\
\hline & & $\mathrm{P}$ & PGR & $\mathrm{P} \times \mathrm{PGR}$ & $\mathrm{P}$ & PGR & $\mathrm{P} \times \mathrm{PGR}$ & $\mathrm{P}$ & PGR & $\mathrm{P} \times \mathrm{PGR}$ \\
\hline \multirow{2}{*}{\multicolumn{2}{|c|}{ SE(d) }} & 0.06 & 0.16 & 0.22 & 0.32 & 0.75 & 1.07 & 0.27 & 0.63 & 0.90 \\
\hline & & 0.13 & 0.32 & 0.45 & 0.65 & 1.53 & 2.16 & 0.54 & 1.28 & 1.82 \\
\hline
\end{tabular}


References

Aditya. 2009. Habitat colour variance in Caralluma sarkariae Lavranos \& Frandsen. Asclepias. Asclepias, 105, 5-8.

Alagesaboopathi. 2012. Effect of IAA and IBA on the rooting of Andrographis macrobotrys nees stem cuttings-an endangered medicinal plant of India. International Journal of Recent Scientific Research, 3(2): 68-70.

Aruna, KC, Karuppusamy S \& Pullaiah T. 2009. Micropropagation of three varieties of Caralluma adscendens via nodal explants. Journal of plant Biochemistry and Biotechnology, 18(1): 121-123.

Audus L. 1963. Plant growth subtance. Interscience Publ. Inc., New York.553p.

Cline MG. 2000. Execution of the auxin replacement apical dominance experiment in temperate woody species. American Journal of Botany, 87(2): 182-190.

Devi SG \& Dhamotharan R. 2016. Caralluma fimbriata-An Important Medicinal Plant: A Review of Its Traditional Uses, Phytochemistry and Pharmacological Properties. International Journal of PharmTech Research, 9(5): 223-230.

Evans ML. 1973. Rapid stimulation of plant cell elongation by hormonal and nonhormonal factors. Bioscience, 23(12): 711718.

Francis G, Aravindakshan M, Gopikumar K \& Valsalakumari P. 1993. Effect of growth substances on rooting of planting materials in black pepper (Piper nigrum L.). Journal of Tropical Agriculture, 31(1): 71-76.

Hitchcock A \& Zimmerman P. 1940. Effects obtained with mixtures of root-inducing and other substances. Contributions from Boyce Thompson Institute, 11: 143-160.

Ingle M \& Venugopal C. 2009. Effect of different growth regulators on rooting of stevia (Stevia rebaudiana Bertoni) cuttings. Karnataka Journal of Agricultural Sciences, 22(2): 455-456.

Jitendra S, Kumawat P, Raj K, Manmohan J, Pandey S \& Singh S. 2009. Propagation of guggal [Commiphora wightii (Arnott)] Bhand through cuttings. Indian Journal of Agroforestry, 11(2): 76-79.

Murthy G, Umesha K, Smitha G \& Krishnamanohar R. 2010. Effect of growth regulators and bio-inoculants on rooting and growth of vanilla stem cuttings. Indian Journal of Horticulture, 67(1): 90-93.

Prakash. 2005. Effect of IBA and NAA on rooting of cuttings of Nerium oleander Linn., Mahatma Phule Krishi Vidyapeeth, Rahuri-413722, Dist. Ahmednagar, Maharashtra (India).

Ramesh M, Rao YN, Kumar MR, Rao AVNA, Prabhakar M \& Reddy BM. 1999. Antinociceptive and anti-inflammatory activity of carumbelloside-I isolated from Caralluma umbellata. Journal of Ethnopharmacology, 68(1-3): 349-352.

Rema J, Mathew P \& Krishnamoorthy B. 2008. Vegetative propagation of allspice. Indian Journal of Horticulture, 65(1): 6568.

Rout G \& Das P. 1994. Somatic embryogenesis and in vitro flowering of 3 species of bamboo. Plant Cell Reports, 13(12): 683-686.

Samydurai P \& Thangapandian V. 2012. Received by Kris Received on 2012-9-10 ID No. B760 Revised on Pages 15 Caralluma species.

Yashwanti, Sharma MK, Singh D, Kumar K \& Verma AK. 2017. Effect of auxins and cytokinin on budding and growth of saplings of bael (Aegle marmelos Correa.)-a medicinal plant. Journal of Agriculture and Ecology, 3: 12-18. 